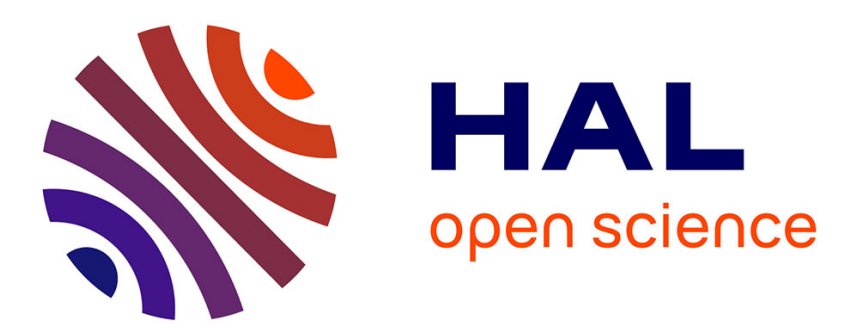

\title{
Synthesis and Reactivity of a Bio-inspired Dithiolene Ligand and its Mo Oxo Complex
}

Jean-Philippe Porcher, Thibault Fogeron, Maria Gomez-Mingot, Lise-Marie Chamoreau, Yun Li, Marc Fontecave

\section{- To cite this version:}

Jean-Philippe Porcher, Thibault Fogeron, Maria Gomez-Mingot, Lise-Marie Chamoreau, Yun Li, et al. Synthesis and Reactivity of a Bio-inspired Dithiolene Ligand and its Mo Oxo Complex. Chemistry - A European Journal, 2016, 22 (13), pp.4447-4453. 10.1002/chem.201504373 . hal-01313058

\section{HAL Id: hal-01313058 https: / hal.sorbonne-universite.fr/hal-01313058}

Submitted on 9 May 2016

HAL is a multi-disciplinary open access archive for the deposit and dissemination of scientific research documents, whether they are published or not. The documents may come from teaching and research institutions in France or abroad, or from public or private research centers.
L'archive ouverte pluridisciplinaire HAL, est destinée au dépôt et à la diffusion de documents scientifiques de niveau recherche, publiés ou non, émanant des établissements d'enseignement et de recherche français ou étrangers, des laboratoires publics ou privés. 


\title{
Synthesis and Reactivity of a Bio-inspired Dithiolene ligand and its Mo-oxo complex
}

\author{
Jean-Philippe Porcher, ${ }^{[a]}$ Thibault Fogeron, ${ }^{[a]}$ Maria Gomez-Mingot, ${ }^{[a]}$ Lise-Marie Chamoreau, ${ }^{[a]}$ Yun \\ $\mathrm{Li}^{*[\mathrm{a}]}$ and Marc Fontecave ${ }^{\star[\mathrm{a}]}$
}

Abstract: An original synthesis of the fused pyrano-quinoxaline dithiolene ligand, qpdt $^{2-}$, is discussed in detail. Specially, the most intriguing step was the introduction of the dithiolene function by the Pd-catalyzed carbon-sulfur coupling reaction. The corresponding $\mathrm{Mo}^{\mathrm{IV} O}$ complex $\left(\mathrm{Bu}_{4} \mathrm{~N}\right)_{2}\left[\mathrm{MoO}(\mathrm{qpdt})_{2}\right] \quad$ (2) enjoyed reversible protonation in a strong acidic medium and remained stable under anaerobic conditions. Besides, 2 was found to be very sensitive towards oxygen forming a planar dithiin derivative. Moreover, the qpdt ${ }^{2-}$ ligand in the presence of $\left[\mathrm{MoCl}_{4}(\mathrm{tBuNC})_{2}\right]$ formed an original tetracyclic structure. The products obtained from the unique reactivity of $\mathrm{qpdt}^{2-}$ have been characterized by X-ray diffraction, mass spectrometry, NMR spectroscopy, UV-Vis spectroscopy and electrochemistry. The plausible mechanisms for the formation of these products are also enclosed.

\section{Introduction}

Six families of Mo or W containing enzymes (oxidoreductases, hydrolases, etc... $)^{[1]}$ have been discovered and characterized structurally by X-ray diffraction methods so far. ${ }^{[2]}$ In general a single $\mathrm{Mo} / \mathrm{W}$ ion is coordinated by molybdopterin (MPT, Figure 1 ), which is an unstable fused pyranopterin system containing a dithiolene chelate. During the catalytic cycle, the oxidation number of $\mathrm{Mo} / \mathrm{W}$ varies from +4 to +6 , while the MPT structure remains unchanged.

Several bioinorganic groups have focused their efforts on synthesizing Mo/W-dithiolene complexes as structural and functional analogues of these active sites. The pioneer work was launched by Holm's group ${ }^{[3]}$ over 20 years ago and was followed by others. ${ }^{[4]}$ We here report the synthesis of a new fused pyranoquinoxaline dithiolene ligand, qpdt $^{2-}$, under its protected form 1 (Figure 1). To our knowledge, only very few examples of such dithiolene ligands have been reported so far. Recently, Basu et al. have developed the synthesis of an analogue of $\mathbf{1}$ and used it as a specific probe for $\mathrm{Pb}^{2+}$ detection. ${ }^{[5]}$ However, this synthetic route required several delicate steps with moderate yields, especially for the pyran ring closure step. No Mo/W complex was reported in their work. Garner and co-workers have synthesized a tricyclic pyranopterin dithiolene ligand system

[a] J.-P. Porcher, T. Fogeron, Dr. M. Gomez-Mingot, Dr. Y. Li, Prof. M. Fontecave

Laboratoire de Chimie des Processus Biologiques, UMR 8229 CNRS, Collège de France, Université Paris 6

11 Place Marcelin Berthelot, 75231 Paris Cedex 05, France. E-mail: yun.xu-li@college-de-france.fr; marc.fontecave@college-defrance.fr

[b] L.-M. Chamoreau

Sorbonne Universités, UPMC Université Paris 6, Institut Parisien de Chimie Moléculaire, UMR 8232 CNRS

4 Place Jussieu, 75252 Paris Cedex 05, France (including the pyrimidine ring) ${ }^{[6]}$ But they failed to complex a $\mathrm{Mo} / \mathrm{W}$ ion. A Co complex was isolated and characterized instead. Burgmayer's group have reported the synthesis of the $\mathrm{Mo}^{\mathrm{IV}} / \mathrm{Mo}^{\mathrm{V}}$ complexes $\mathrm{Tp}^{*} \mathrm{MoO}$ (pyrano- $\mathrm{S}_{2} \mathrm{BMOPP}$ ), where $\mathrm{Tp}^{*}$ is tris(3,5dimethylpyrazolyl)hydroborate and "pyrano- $\mathrm{S}_{2} \mathrm{BMOPP}$ " is a tricyclic pyranopterin dithiolene chelate. The pyran ring is formed through a solvent-dependent spontaneous cyclization. ${ }^{[7]}$

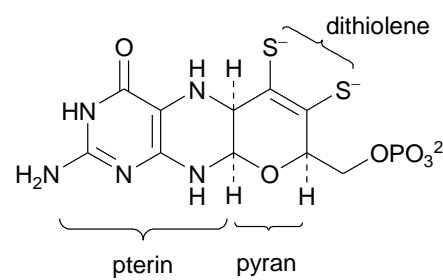

MPT

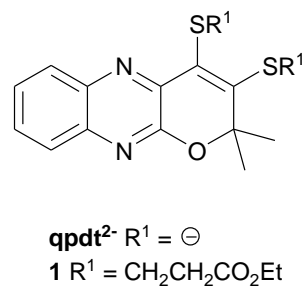

qpdt $^{2-} \mathrm{R}^{1}=\Theta$ $1 \mathrm{R}^{1}=\mathrm{CH}_{2} \mathrm{CH}_{2} \mathrm{CO}_{2} \mathrm{Et}$
Figure 1. The structures of MPT, ligand qpdt ${ }^{2-}$ and its protected form 1.

In a previous communication we have shown that qpdt $^{2-}$ can be used to synthesize a Mo ${ }^{\mathrm{IV}} \mathrm{O}$ complex $\left(\mathrm{Bu}_{4} \mathrm{~N}\right)_{2}\left[\mathrm{MoO}(\mathrm{qpdt})_{2}\right]$ (2, Figure 2). This complex acts as a remarkable catalyst for electro- and photo- reduction of protons into $\mathrm{H}_{2}$ in organic solvents. ${ }^{[8]}$ In the current study, we describe reactions of this complex in the presence of protons and oxygen. Finally, the reactivity of the dithiolene towards $\left[\mathrm{MoCl}_{4}(\mathrm{tBuNC})_{2}\right]$ is also reported. All these reactions illustrate the unique chemical reactivity of this original biomimetic complex.

\section{Results and Discussion}

\section{Synthesis of the ligand}

As regards the synthetic strategy, it seems that the great difficulty resides in the pyran ring closure step. ${ }^{[5]}$ To circumvent this problem, we chose to first prepare the tricyclic skeleton, and to introduce the dithiolene function in a second stage. For this purpose, the bromo-enol $\mathbf{3}$ was synthesized. 2,3dichloroquinoxaline (4), underwent a Sonogashira coupling followed by a pyran ring closure step with sodium methylate to afford methyl enol-ether $\mathbf{6}$, according to a reported procedure. ${ }^{[9]}$ After hydrolysis of 6 under acidic conditions, controlled monobromination of 7 at low temperature afforded 3 in $89 \%$ yield (Scheme 1). 
<smiles>[X]c1ccc2nc3c(nc2c1)C([X])C(=O)C(C)(C)O3</smiles>

8<smiles>CCOC1=Cc2nc3ccccc3nc2OC1(C)C</smiles>
$6 R^{2}=M e$
$7 R^{2}=H$ (iii) $^{2}$

$\downarrow$ (iv)<smiles>[X]C1=C(O)C(C)(C)Oc2nc3ccccc3nc21</smiles>

$3 \mathrm{X}=\mathrm{Br} ; 9 \mathrm{X}=1$

$\downarrow$ (vi)<smiles>[X]C1=C(OCC)C(C)(C)Oc2nc3ccccc3nc21</smiles>

$12 \mathrm{X}=\mathrm{Br} ; 13 \mathrm{X}=1$

Scheme 1. Tentative formation of dithiocarbonate 8. Reaction conditions: (i) $\mathrm{HC} \equiv \mathrm{CC}(\mathrm{OH}) \mathrm{Me}_{2}, \mathrm{PdCl}_{2}\left(\mathrm{PPh}_{3}\right)_{2}$ (3\%), Cul (6\%), iPr ${ }_{2} \mathrm{NEt}, \mathrm{THF}, \mathrm{RT}, 16 \mathrm{~h}$ (84\%); (ii) MeONa, MeOH, reflux, $1.5 \mathrm{~h},(65 \%)$; (iii) $\mathrm{HCl}(1 \mathrm{M}), \mathrm{THF}, \mathrm{RT}, 16 \mathrm{~h}$ (95\%); (iv) for 3: $\mathrm{Br}_{2}, \mathrm{CH}_{2} \mathrm{Cl}_{2}, 0^{\circ} \mathrm{C}, 0.5 \mathrm{~h}\left(89 \%\right.$ ); for $9: \mathrm{I}_{2}, \mathrm{CH}_{2} \mathrm{Cl}_{2}, 0^{\circ} \mathrm{C}, 0.5 \mathrm{~h}$ (68\%); (v) a) $\operatorname{PrOC}(\mathrm{S}) \mathrm{SK}$; b) $70 \% \mathrm{HClO}_{4}$; (vi) $\mathrm{Tf}_{2} \mathrm{O}, \mathrm{Pr}_{2} \mathrm{NEt}, \mathrm{CH}_{2} \mathrm{Cl}_{2}, \mathrm{RT}$, $89 \%$ for 12 and $68 \%$ for 13 .

In order to prepare the dithiocarbonate 8 as a protected dithiolene ligand, compound $\mathbf{3}$ was first treated with O-isopropylxanthic acid potassium salt, a classical method for introducing a dithiocarbonate from an $\alpha$-bromoketone. ${ }^{[10]}$ Despite many attempts under different experimental conditions (reaction temperatures, solvents...), no nucleophilic substitution product was obtained. Only the starting compound $\mathbf{3}$ was detectable by ${ }^{1} \mathrm{H}$ NMR spectroscopy. The same results were obtained even when the iodo-enol $\mathbf{9}$ was employed as the starting reagent. It is likely that, in both $\mathbf{3}$ and $\mathbf{9}$, the keto-enol equilibrium is strongly displaced towards the enol form, according to the ${ }^{1} \mathrm{H}$ NMR data $\left(\delta_{\mathrm{OH}}=8.42 \mathrm{ppm}, 1 \mathrm{H}\right.$ for 3 and $\delta_{\mathrm{OH}}=8.47 \mathrm{ppm}, 1 \mathrm{H}$ for $9, \mathrm{D}_{2} \mathrm{O}$ exchangeable for both protons) and therefore the substitution reaction by a S-nucleophile is disfavored.

Itoh et al. have developed a general carbon-sulfur bond formation method via a palladium-catalyzed coupling reaction of aryl bromides/triflates and thiols. ${ }^{[11]}$ In order to insert a thiol surrogate, we extended this methodology to the vinyl bromide function in 3. Thioacetic acid and iso-octyl-3-mercaptopropionic acid were tested (Scheme 2). The dimerization product $\mathbf{1 0}$ was obtained in both cases. This result strongly suggests that a deprotection step assisted by the adjacent enolate occurred after thiol insertion, resulting in a highly nucleophile thiolene intermediate 11 (Scheme 2). However, what is remarkable is that a protected thiol could indeed replace a vinyl bromide under this condition.

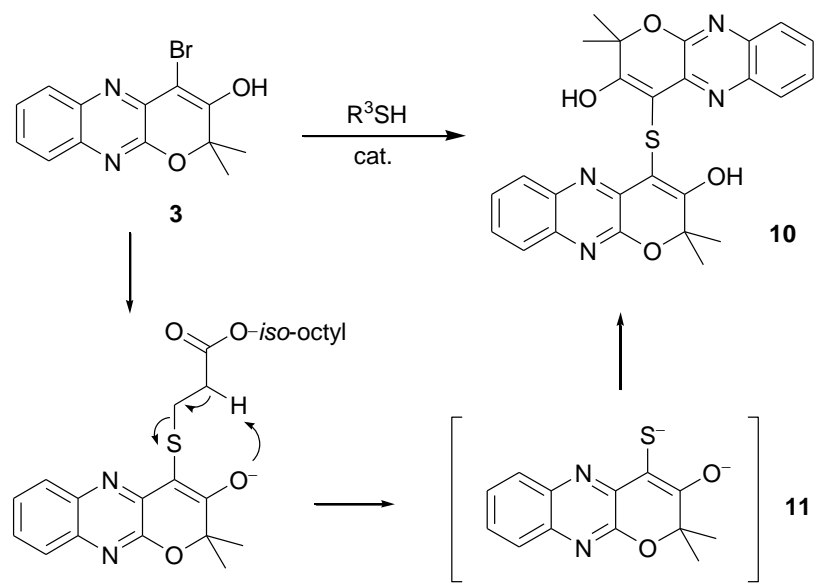

Scheme 2. Formation of dimer 10. Reaction conditions: $\mathrm{Pd}(\mathrm{OAc})_{2}(2.5 \%)$, Xantphos (5\%), $\quad \mathrm{Pr}_{2} \mathrm{NEt}$, 1,4-dioxane, $80{ }^{\circ} \mathrm{C}, 3 \mathrm{~h} ; \mathrm{R}^{3} \mathrm{SH}=\mathrm{AcSH}$ or $\mathrm{HSCH}_{2} \mathrm{CH}_{2} \mathrm{CO}_{2}$ (iso-octyl). Reaction yields $=77 \%$ and $70 \%$, respectively.

We decided next to prepare the corresponding bromo-vinyl triflate 12 and iodo-vinyl triflate 13 under standard conditions $\left(\mathrm{Tf}_{2} \mathrm{O} / \mathrm{Pr}_{2} \mathrm{NEt} / \mathrm{CH}_{2} \mathrm{Cl}_{2}\right.$, Scheme 1). Both 12 and 13 were submitted to a double palladium-catalyzed cross-coupling reaction with two equivalents of $\mathrm{HSCH}_{2} \mathrm{CH}_{2} \mathrm{CO}_{2} \mathrm{Et}$. The iodo derivative 13 gave a complex mixture after the reaction.

Table 1. Synthesis of 1 by a double Pd-catalyzed cross-coupling reaction
${ }^{B r}$

12

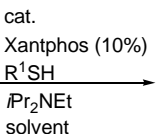

$110^{\circ} \mathrm{C}, 3 \mathrm{~h}$

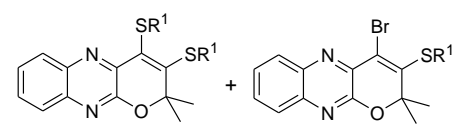

14 $\mathrm{R}^{1}=\mathrm{CH}_{2} \mathrm{CH}_{2} \mathrm{CO}_{2} \mathrm{Et}$

\begin{tabular}{|c|c|c|c|c|c|}
\hline Entry & $\begin{array}{l}\text { cat. } \\
\text { (equiv.) }\end{array}$ & $\begin{array}{l}\mathrm{R}^{1} \mathrm{SH} \\
\text { (equiv.) }\end{array}$ & $\begin{array}{l}\mathrm{Pr}_{2} \mathrm{NEt} \\
\text { (equiv.) }\end{array}$ & solvent & $1 / 14^{[\mathrm{a}]}$ \\
\hline 1 & $\begin{array}{l}\mathrm{Pd}(\mathrm{OAc})_{2} \\
(0.1)\end{array}$ & 2.2 & 3 & dioxane & $\begin{array}{l}\text { no } \\
\text { reaction }\end{array}$ \\
\hline 2 & $\begin{array}{l}\mathrm{Pd}(\mathrm{dba})_{2} \\
(0.1)\end{array}$ & 2.2 & 3 & DMF & $57 / 43$ \\
\hline 3 & $\begin{array}{l}\mathrm{Pd}_{2}(\mathrm{dba})_{3} \\
(0.05)\end{array}$ & 2.2 & 3 & DMF & $51 / 49$ \\
\hline 4 & $\begin{array}{l}\mathrm{Pd}(\mathrm{dba})_{2} \\
(0.1)\end{array}$ & 4 & 5 & dioxane & $58 / 42$ \\
\hline 5 & $\begin{array}{l}\mathrm{Pd}_{2}(\mathrm{dba})_{3} \\
(0.05)\end{array}$ & 4 & 5 & dioxane & $54 / 46$ \\
\hline 6 & $\begin{array}{l}\mathrm{Pd}(\mathrm{dba})_{2} \\
(0.1)\end{array}$ & 2.2 & 3 & dioxane & $\begin{array}{l}75 / 25 \\
(66 / 21)^{[b]}\end{array}$ \\
\hline 7 & $\begin{array}{l}\mathrm{Pd}_{2}(\mathrm{dba})_{3} \\
(0.05)\end{array}$ & 2.2 & 3 & dioxane & $\begin{array}{l}88 / 12 \\
(77 / 8)^{[b]}\end{array}$ \\
\hline
\end{tabular}

${ }^{[\mathrm{a}]}$ The ratios are determined by ${ }^{1} \mathrm{H}$ NMR spectroscopy. ${ }^{[\mathrm{b}]}$ The yields correspond to isolated products. 
However, starting with $\mathbf{1 2}$, it was possible to isolate the protected dithiolene ligand $\mathbf{1}$, along with the mono-substituted product 14 (Table 1). As expected, the vinyl triflate function was more reactive than the vinyl bromide one. In order to optimize the yield of $\mathbf{1}$, different conditions (solvents, catalysts and the amount of the thiol) were tested. The results are listed in Table 1. The best result was obtained with $\mathrm{Pd}_{2}(\mathrm{dba})_{3}(5 \%)$ and Xantphos $(10 \%)$ in dioxane in the presence of 2.2 equiv. of $\mathrm{HSCH}_{2} \mathrm{CH}_{2} \mathrm{CO}_{2} \mathrm{Et}$ and 3 equiv. of $\mathrm{Pr}_{2} \mathrm{NEt}$ at $110{ }^{\circ} \mathrm{C}$ (entry 7 ). Under the same conditions, $\mathrm{Pd}(\mathrm{dba})_{2}(10 \%)$ gave a slightly lower yield of $\mathbf{1}$ (entry 6$). \mathrm{Pd}(\mathrm{OAc})_{2}$ did not catalyze this reaction (entry 1). DMF is a less good solvent than 1,4-dioxane (entries 2 and 3 ). Finally, the isolated compound $\mathbf{1 4}$ could be again transformed to 1 in $75 \%$ yield under the same conditions. Both 1 and $\mathbf{1 4}$ are fully characterized, especially by ${ }^{1} \mathrm{H}$ and ${ }^{13} \mathrm{C}$ NMR spectroscopy (Figure S1- S4, Supporting Information). Thus, we show for the first time that this cross coupling reaction leading to sulfurated compounds can be extended to functionalized vinyl derivatives.

\section{Complexation and reactivity of 1 towards $\mathrm{Mo}^{4+}$ ion}

1 was treated with $t \mathrm{BuOK}$ under anaerobic conditions to generate the dithiolene ligand $\mathrm{qpdt}^{2-}$ (Figure 1). Due to its instability, this latter was not isolated and was directly reacted with $\mathrm{K}_{3} \mathrm{Na}\left[\mathrm{MoO}_{2}(\mathrm{CN})_{4}\right] \cdot 6 \mathrm{H}_{2} \mathrm{O}^{[12]}$ to afford the square planar pyramidal, mononuclear complex $\left(\mathrm{Bu}_{4} \mathrm{~N}\right)_{2}\left[\mathrm{Mo}^{\mathrm{IV}} \mathrm{O}(\mathrm{qpdt})_{2}\right] \quad$ (2, Figure 2) after cation exchange with $\mathrm{Bu}_{4} \mathrm{NBr}^{[8]}$

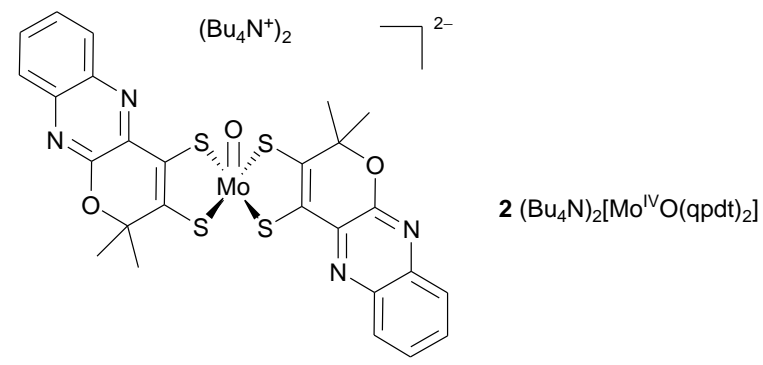

Figure 2. The Mo-oxo complex $\left(\mathrm{Bu}_{4} \mathrm{~N}\right)_{2}\left[\mathrm{MoO}(\mathrm{qpdt})_{2}\right](2)$.

\subsection{Reactivity of $\left(\mathrm{Bu}_{4} \mathrm{~N}\right)_{2}\left[\mathrm{Mo}^{\mathrm{IV}} \mathrm{O}(\mathrm{qpdt})_{2}\right]$ towards protons}

Figure 3 shows the UV-Vis spectrum of $50 \mu \mathrm{M}$ $\left.\left(\mathrm{Bu}_{4} \mathrm{~N}\right)_{2}\left[\mathrm{Mo}^{\mathrm{IV}} \mathrm{O} \text { (qpdt) }\right)_{2}\right]$ in $\mathrm{CH}_{3} \mathrm{CN}$ with its three characteristic absorption bands at 322,374 and $470 \mathrm{~nm}$. The addition of increasing amounts of trifluoroacetic acid (TFA) resulted in drastic changes of the UV-visible spectrum. After addition of 1 equivalent of TFA, a first species was formed with a characteristic absorption at 592 and $440 \mathrm{~nm}$. Further addition of TFA led to evolution of a second species with a main prominent absorption band at $564 \mathrm{~nm}$ and a shoulder at $510 \mathrm{~nm}$ and three small bands in the $300-400 \mathrm{~nm}$ range. The mass spectrum of the species resulting from the reaction of 2 with 10 equivalents of TFA demonstrates a double protonation of complex $\mathbf{2}$ with a mass corresponding to $\left\{\left[\mathrm{MoO}(\mathrm{qpdt})_{2}\right]+2 \mathrm{H}^{+}\right\}$., nicely fitting with the theoretical spectrum, $\mathrm{m} / \mathrm{z}=663.9$ (calcd. for $\mathrm{C}_{26} \mathrm{H}_{22} \mathrm{MoN}_{4} \mathrm{O}_{3} \mathrm{~S}_{4}: \mathrm{m} / \mathrm{z}=663.9629$ ) (Figure S5). Thus, reaction of 2 with one equivalent of TFA quantitatively converts it into a mono-protonated species while a large excess of acid is required to displace the equilibrium towards the doubly protonated species.

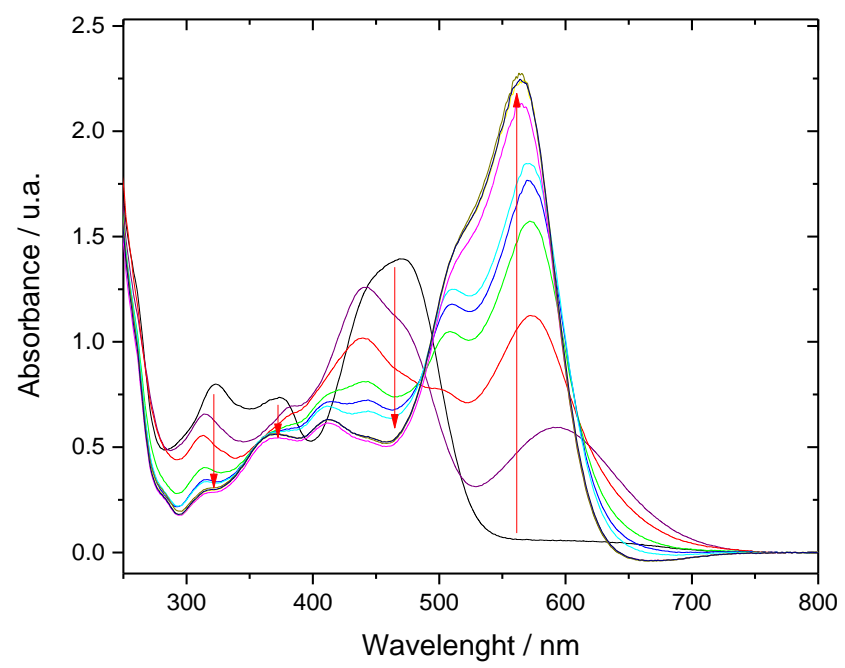

Figure 3. UV-Vis spectrum of $50 \mu \mathrm{M}\left(\mathrm{Bu}_{4} \mathrm{~N}\right)_{2}\left[\mathrm{Mo}^{\mathrm{IV}} \mathrm{O}(\mathrm{qpdt})_{2}\right]$ in acetonitrile (black curve). Additions of TFA: 1equiv. (purple), 2 equiv. (red), 3 equiv. (green), 4 equiv. (blue), 5 equiv. (light blue), 10 equiv. (magenta), 25 equiv. (yellow), 50 equiv. (dark yellow) and 100 equiv. (navy).

The cyclic voltammogram of 2 in $\mathrm{CH}_{3} \mathrm{CN}$ displays a reversible redox couple at $-0.19 \mathrm{~V} v s$. $\mathrm{Ag} / \mathrm{AgCl}$ electrode that has been assigned to the $\mathrm{Mo}^{\mathrm{IV}} / \mathrm{Mo}^{\mathrm{V}}$ couple. ${ }^{[8]}$ Addition of TFA triggers a shift of the potential towards more positive potentials, with a slight loss of current intensity (Figure 4). This shift follows the same trend than that of the absorbance at $564 \mathrm{~nm}$ for the same number of equivalents in TFA (Figure 5). Similar results have been recently published by Dicks et al. ${ }^{[13]}$ with simplified asymmetric ene-1,2-dithiolate Co complexes, [ $\left(n^{5}\right.$ $\left.\left.\mathrm{C}_{5} \mathrm{H}_{5}\right) \mathrm{Co}\{\mathrm{SC}(\mathrm{H}) \mathrm{CRS}\}\right]$ where $[\mathrm{R}=$ pyridine-3-yl or pyrazine-2-yl]. In this work, they observed that the presence of a $5: 1$ excess of TFA facilitated the reduction of the complexes, i.e. the reduction occurred at more positive potentials. This was attributed to the protonation of a pyrazine-2-yl ring $\mathrm{N}$ atom. Our previous DFT calculations showed that $\mathrm{N}$ atom of the central cycle of $\mathbf{2}$ is likely to be the first protonation site. ${ }^{[8]}$ A second protonation on the same cycle can occur however less favorably because of electrostatic repulsion. These protonation events facilitate reduction of 2 , explaining the low overpotential observed during photo- and electro- proton reduction catalyzed by 2 . 


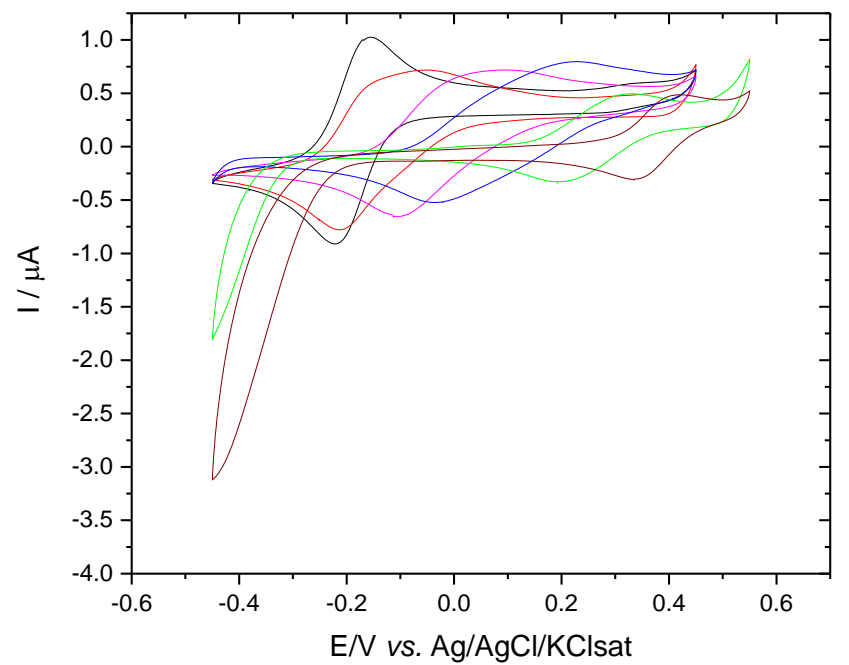

Figure 4. Cyclic voltammograms of $1 \mathrm{mM}$ solutions of $\left(\mathrm{Bu}_{4} \mathrm{~N}\right)_{2}\left[\mathrm{Mo}^{\mathrm{iv}} \mathrm{O}(\mathrm{qpdt})_{2}\right]$ in $0.1 \mathrm{M}$ TBAP in $\mathrm{CH}_{3} \mathrm{CN}$ under $\mathrm{Ar}$ conditions in the presence of TFA: no acid (black), $1 \mathrm{mM}$ (red), $3 \mathrm{mM}$ (magenta), $5 \mathrm{mM}$ (blue), $10 \mathrm{mM}$ (green) and $25 \mathrm{mM}$ (brown) TFA. Further additions of TFA have no effect on the CV. In all cases the third scan is represented. Scan rate $50 \mathrm{mV} \mathrm{s}^{-1}$; glassy carbon electrode.

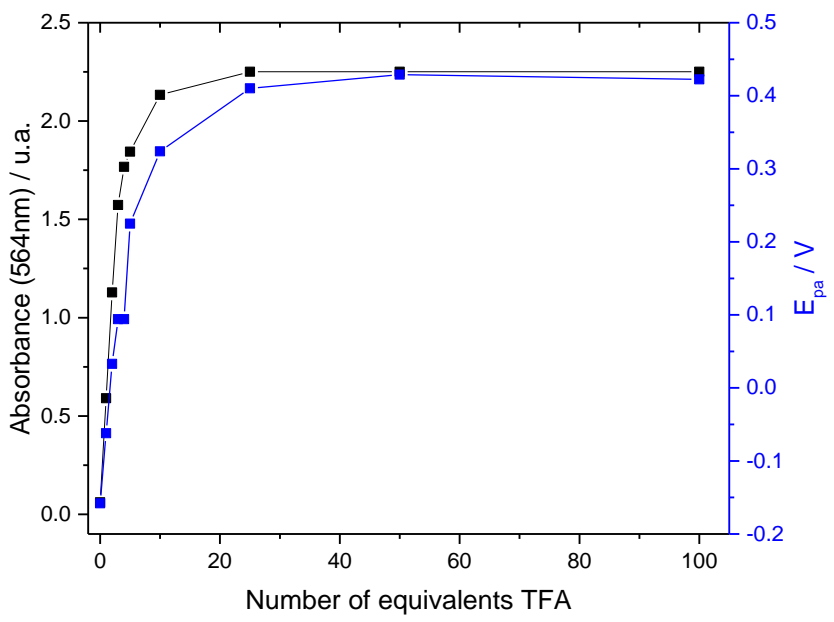

Figure 5. Plot of the absorbance of $\left(\mathrm{Bu}_{4} \mathrm{~N}\right)_{2}\left[\mathrm{Mo}^{\mathrm{IV}} \mathrm{O}(\mathrm{qpdt})_{2}\right]$ (black squares) at $564 \mathrm{~nm}$ and the corresponding anodic potential peak (blue squares) as a function of the number of equivalents of TFA.

Interestingly, the shift of $600 \mathrm{mV}$ on the peak potential of the $\mathrm{Mo}^{\mathrm{IV}} / \mathrm{Mo}^{\mathrm{V}}$ couple upon addition of 100 equivalents of TFA turned out to be reversed upon subsequent neutralization with base (triethylamine, $\mathrm{Et}_{3} \mathrm{~N}$ ) (Figure S6). This reversibility was also observed by UV-visible spectroscopy (Figure S7). These data show that under anaerobic and strong acidic conditions, $\left.\left(\mathrm{Bu}_{4} \mathrm{~N}\right)_{2}[\mathrm{MoO} \text { (qpdt) })_{2}\right]$ (2) is not degraded. It undergoes a reversible protonation process, which can be monitored by UVvisible spectroscopy and cyclic voltammetry.

\subsection{Reactivity of $\left(\mathrm{Bu}_{4} \mathrm{~N}\right)_{2}\left[\mathrm{Mo}{ }^{\mathrm{IV}} \mathrm{O}(\mathrm{qpdt})_{2}\right]$ towards $\mathrm{O}_{2}$}

In solution $\left(\mathrm{CH}_{3} \mathrm{CN}\right.$ or $\left.\mathrm{CDCl}_{3}\right)$, complex 2 is sensitive to $\mathrm{O}_{2}$. The yellow-green color turned almost instantaneously to orange under exposure to air. The oxidized product was isolated and characterized as the dithiin derivative 15. Single crystals were obtained as orange plates by slow evaporation of an acetonitrile solution containing the crude product. An ORTEP diagram of the molecular structure of $\mathbf{1 5}^{[14]}$ shown in Figure 6 reveals a highly conjugated molecule with nearly all the atoms in one plane.

(A)

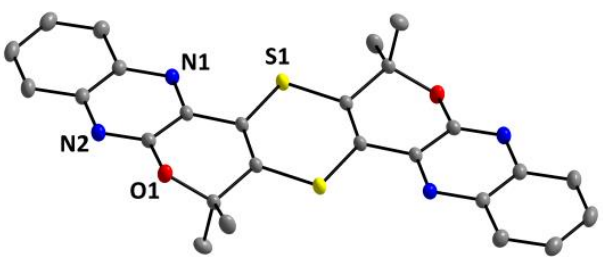

(B)

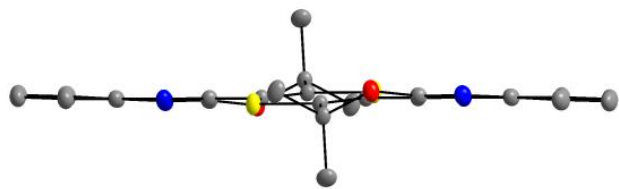

Figure 6. Crystal structure (ellipsoids drawn at $50 \%$ probability) of $\mathbf{1 5}$ (A) with nearly all the atoms in one plane $(B)$. Hydrogen atoms are omitted for clarity.

The proposed mechanism for the formation of $\mathbf{1 5}$ is depicted in Scheme 3. During the oxidative dimerization reaction, 2 first lost its metal ion to form the bis-disulfide 16 , then a rearrangement took place to give the more stable dithiin 15 by elimination of two sulfur atoms of the ligand. This hypothesis was confirmed by positive-ion electrospray mass spectra of $\mathbf{2}$ in acetonitrile solution upon exposure to air after 1 and 30 minutes, respectively. A peak at $\mathrm{m} / \mathrm{z}=549$ (corresponding to $[16+\mathrm{H}]^{+}$) in the first case (Figure S8), and another one at $\mathrm{m} / \mathrm{z}=485$ (corresponding to $\left[15+\mathrm{H}^{+}\right.$) in the second case (Figure S9), were observed. This mechanism is comparable to the previously reported one for the air oxidation of disodium dimercaptomaleodinitrile ( $\left.\mathrm{Na}_{2} \mathrm{mnt}\right)$ giving tetracyano-1,4-dithiin as the product. ${ }^{[15]}$ To our knowledge, it is the first time that the air oxidation product of a $\mathrm{Mo}^{\mathrm{IV}}$ (dithiolene) ${ }_{2}$ complex was structurally characterized.

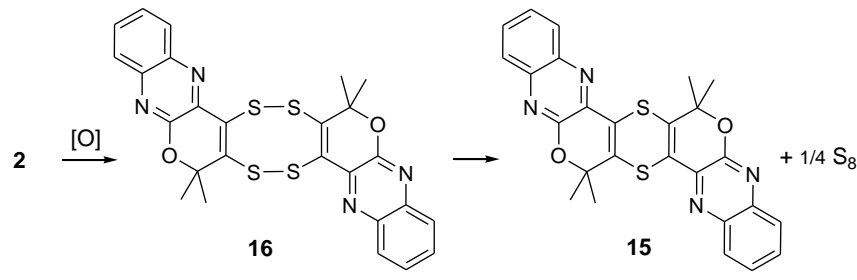

Scheme 3. Formation of dithiin 15 from $\left[\mathrm{Mo}^{\mathrm{IV}} \mathrm{O}(\mathrm{qpdt})_{2}\right]^{2-}$ under air oxidation. 


\subsection{Reactivity of $\mathrm{qpdt}^{2-}$ towards $\left[\mathrm{MoCl}_{4}(t \mathrm{BuNC})_{2}\right]$}

The de-protected ligand qpdt $^{2-}$ was allowed to react with another $\mathrm{Mo}^{4+}$ reagent $\left[\mathrm{MoCl}_{4}(t \mathrm{BuNC})_{2}\right]$, in order to generate a new bisdithiolene bis-isocyanide $\mathrm{Mo}^{\mathrm{IV}}$ complex $\left[\mathrm{Mo}^{\mathrm{IV}}(\mathrm{qpdt})_{2}(t \mathrm{BuNC})_{2}\right](\mathbf{1 7}$, Scheme 4$)$, by a previously reported procedure. ${ }^{[16]}$ The starting $\left[\mathrm{MoCl}_{4}(t \mathrm{BuNC})_{2}\right]$ was generated in situ by $\left.\left[\mathrm{MoCl}_{4}\left(\mathrm{CH}_{3} \mathrm{CN}\right)_{2}\right)\right]$ and an excess of $t$ BuNC. However, no trace of $\mathbf{1 7}$ could be detected by electrospray mass spectroscopy. A new tetracyclic iminothiazole derivative $\mathbf{1 8}$ was isolated instead. Single-crystal X-ray analysis of $18^{[14]}$ revealed a quite original tetracyclic structure with a $\mathrm{C}=\mathrm{S}$ bond on the pyran ring (Figure 7 ).

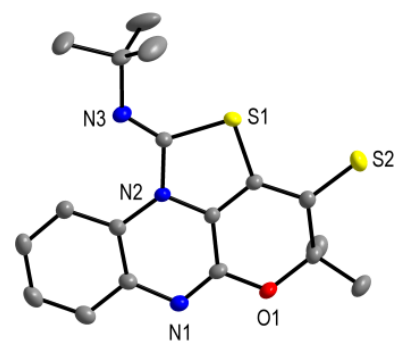

Figure 7. ORTEP representation of imino-thiazole 18 at $50 \%$ probability. Hydrogen atoms are omitted for clarity.

In a separate experiment, the $\mathrm{qpdt}^{2-}$ ligand was treated with tBuNC in the absence of $\left.\left[\mathrm{MoCl}_{4}\left(\mathrm{CH}_{3} \mathrm{CN}\right)_{2}\right)\right]$ and 18 was not observed by ${ }^{1} \mathrm{H}$ NMR spectroscopy. The proposed mechanism is outlined in Scheme 4 . We suggest that due to the presence of the neighboring nitrogen atom, a rearrangement took place after the formation of complex [Mo(qpdt $\left.)_{2}(t B u N C)_{2}\right] 17$, leading to the original tetracyclic imino-thiazol 18.

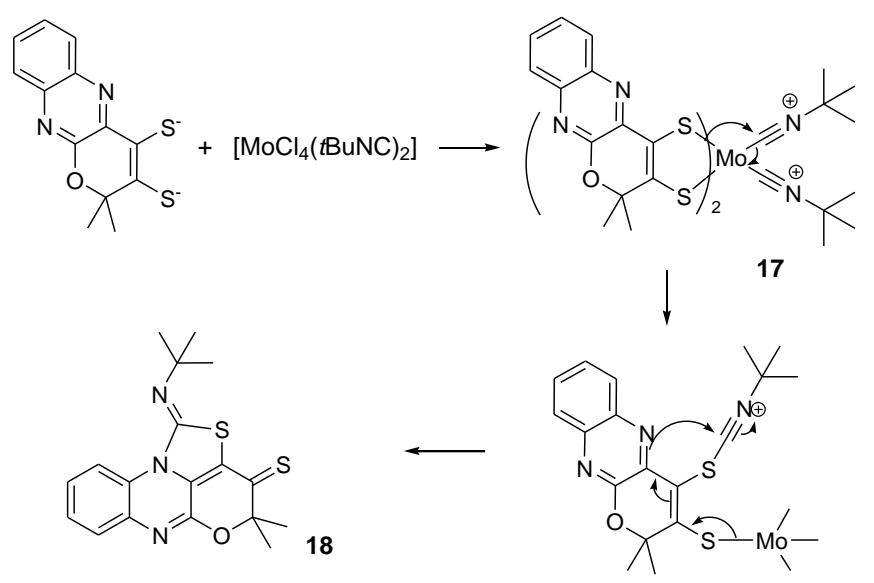

Scheme 4. A proposed mechanism for the formation of 18.

\section{Conclusions}

We have developed an unprecedented efficient method to synthesize a bio-inspired dithiolene ligand which is closely related to the biological molybdopterin ligand. The corresponding Mo-oxo complex, which nicely mimics the active site of Mo-enzymes, with Mo being bis-coordinated by this ligand was also obtained. ${ }^{[8]}$ Investigation of the reactivity of the Modithiolene assembly towards protons, oxygen and isocyanides led to new reactions and original products, which have been spectroscopically and structurally characterized. This provides new insights into Mo-dithiolene chemistry which might have some biological relevance.

\section{Experimental Section}

\section{General methods}

All starting materials were commercially available and were used without further purification. Solvents were purified by an MBRAUN SPS-800 Solvent Purification System. All reactions were carried out under air atmosphere unless specified. ${ }^{1} \mathrm{H}$ and ${ }^{13} \mathrm{C}$ NMR spectra were recorded on a Bruker Avance-III 300 NMR spectrometer $\left(300 \mathrm{MHz}\right.$ for ${ }^{1} \mathrm{H}, 75 \mathrm{MHz}$ for ${ }^{13} \mathrm{C}$ ) at room temperature. High-resolution mass spectra (HRMS) were recorded on a LCT Premier XE mass spectrometer using ESI (electrospray ionization) at Institut de Chimie des Substances Naturelles in Gif-sur-Yvette. Mass spectra (MS) were recorded on an Applied Biosystems QSTAR pulsar I mass spectrometer using ESI (electrospray ionization) at Muséum National d'Histoire Naturelle (Paris). Flash chromatography was performed on Grace Reverlis ${ }^{\circledR}$ x2 with corresponding cartridges. UV-Vis spectra were recorded using a Cary 100 UV-Vis spectrophotometer instrument (Agilent). Voltammetric measurements were performed using a SP 300 Bio-Logic potentiostat (Bio-Logic Science Instruments SAS). All measurements were conducted using a three electrode system. A platinum wire, a glassy carbon (1 $\mathrm{mm}$ diameter) and a saturated $\mathrm{Ag} / \mathrm{AgCl} / \mathrm{KCl}$ saturated electrode were used as a counter and reference electrodes, respectively. Cyclic voltammograms were recorded in anhydrous acetonitrile (Sigma) containing $0.1 \mathrm{M}$ tetrabutylammonium perchlorate (TBAP, Sigma) in anaerobic conditions at room temperature.

Synthesis of 3, 7 and 12 were reported earlier. ${ }^{[8]}$

4-(3-chloroquinoxalin-2-yl)-2-methylbut-3-yn-2-ol

(5). Under an Ar atmosphere, to a solution of 2,3-dichloroquinoxaline $(10 \mathrm{~g}, 50.2 \mathrm{mmol})$ in dry THF $(45 \mathrm{~mL})$ were added Cul $(619 \mathrm{mg}$, $3.26 \mathrm{mmol}$ ) and $\mathrm{PdCl}_{2}\left(\mathrm{PPh}_{3}\right)_{2}(1.056 \mathrm{~g}, 1.51 \mathrm{mmol})$. $\quad \mathrm{Pr}_{2} \mathrm{NEt}$ (16.6 mL, $95.38 \mathrm{mmol}$ ) was slowly added via a syringe to give an orange suspension. 2-methylbut-3-yn-2-ol (4.217g, 50.2 mmol) was then slowly added to the mixture via a cannula needle. The suspension was stirred at room temperature overnight and led to a dark orange suspension. The reaction mixture was concentrated in vacuo and extracted with $\mathrm{CH}_{2} \mathrm{Cl}_{2}$ three times. The combined organic layers were dried over magnesium sulfate and concentrated in vacuo. Purification of 
the crude product by flash chromatography over silica gel using EtOAc : cyclohexane $(1: 4)$ as an eluent gave a brown oil (10.452 g, $84 \%) .{ }^{1} \mathrm{H}$ NMR $\left(\mathrm{CDCl}_{3}\right) \delta 8.11(\mathrm{~m}, 1 \mathrm{H}, \mathrm{Ar}), 8.02(\mathrm{~m}$, $1 \mathrm{H}, \mathrm{Ar}), 7.86-7.74(\mathrm{~m}, 2 \mathrm{H}, \mathrm{Ar}), 2.39\left(\mathrm{~s}, 1 \mathrm{H}, \mathrm{D}_{2} \mathrm{O}\right.$ exchangeable, $\mathrm{OH}), 1.74\left(\mathrm{~s}, 6 \mathrm{H}, \mathrm{CH}_{3}\right)$. This spectrum was identical to the previously reported one. ${ }^{[9]}$

3-Methoxy-2,2-dimethyl-2H-1-oxa-9,10-diaza-anthracene (6). Under an $\mathrm{Ar}$ atmosphere, sodium hydride (60\% in mineral oil, $8.48 \mathrm{~g}, 212 \mathrm{mmol}$ ) was added in small portions to methanol (66 $\mathrm{mL}$ ) at $0^{\circ} \mathrm{C}$. The white suspension was allowed to stir for 10-15 minutes at room temperature until no more gas evolvement could be observed. A solution of 5 (10.452 g $42.4 \mathrm{mmol})$ in 17 $\mathrm{mL}$ of methanol was slowly added via a cannula needle. The green/dark suspension was stirred at $80{ }^{\circ} \mathrm{C}$ for $1.5 \mathrm{~h}$. MeOH was evaporated under reduced pressure. The usual work-up with EtOAc gave a crude product, which was purified by flash chromatography over silica gel (eluting with EtOAc : cyclohexane, $15: 85) .5 .951 \mathrm{~g}(58 \%)$ was obtained. ${ }^{1} \mathrm{H}$ NMR $\left(\mathrm{CDCl}_{3}\right) \delta 7.86(\mathrm{~m}, 1 \mathrm{H}, \mathrm{Ar}), 7.78(\mathrm{~m}, 1 \mathrm{H}, \mathrm{Ar}), 7.52(\mathrm{~m}, 2 \mathrm{H}, \mathrm{Ar})$, $5.95(\mathrm{~s}, 1 \mathrm{H}, \mathrm{CH}), 3.67\left(\mathrm{~s}, 3 \mathrm{H}, \mathrm{CH}_{3}\right), 1.67\left(\mathrm{~s}, 6 \mathrm{H}, \mathrm{CH}_{3}\right)$. This spectrum was identical to the previously reported one. ${ }^{[9]}$

4-iodo-2,2-dimethyl-2H-1-oxa-9,10-diaza-anthracen-3-ol (9). Under an $\mathrm{Ar}$ atmosphere, a solution of $\mathrm{I}_{2}(111 \mathrm{mg}, 0.438 \mathrm{mmol})$ in dry $\mathrm{CH}_{2} \mathrm{Cl}_{2}(1 \mathrm{~mL})$ was added dropwise to a solution of 8 (100 $\mathrm{mg}, 0.438 \mathrm{mmol})$ in dry $\mathrm{CH}_{2} \mathrm{Cl}_{2}(1.5 \mathrm{~mL})$ via a syringe at $0^{\circ} \mathrm{C}$. A suspension gradually formed. After $30 \mathrm{~min}$, the reaction mixture was neutralized by careful addition of an aqueous solution of $\mathrm{NaHCO}_{3}$. The usual work-up with $\mathrm{CH}_{2} \mathrm{Cl}_{2}$ gave a crude product, which was purified by flash chromatography over silica gel (eluting with THF : $\mathrm{CH}_{2} \mathrm{Cl}_{2}, 5: 95$ ). A yellow powder (106 mg, $68 \%$ ) was obtained. ${ }^{1} \mathrm{H}$ NMR $\left(\mathrm{CDCl}_{3}\right): \delta 8.47$ (bs, $1 \mathrm{H}, \mathrm{D}_{2} \mathrm{O}$ exchangeable, $\mathrm{OH}) ; 7.59(\mathrm{~d}, \mathrm{~J}=8.0 \mathrm{~Hz}, 1 \mathrm{H}, \mathrm{Ar}), 7.42-7.20(\mathrm{~m}$, $3 \mathrm{H}, \mathrm{Ar}), 1.70\left(\mathrm{~s}, 6 \mathrm{H}, 2 \mathrm{CH}_{3}\right) .{ }^{13} \mathrm{C} \mathrm{NMR}\left(\mathrm{CDCl}_{3}\right): \delta 187.31(\mathrm{C})$, $151.50(\mathrm{C}), 138.45(\mathrm{C}), 133.75(\mathrm{C}), 128.18(\mathrm{CH}), 127.24(\mathrm{C})$, $125.46(\mathrm{CH}), 125.67(\mathrm{CH}), 114.79(\mathrm{CH}), 86.81(\mathrm{C}), 70.55(\mathrm{C})$, $27.29\left(2 \mathrm{CH}_{3}\right)$. HRMS: $\mathrm{m} / z$ calcd. for $\mathrm{C}_{13} \mathrm{H}_{12} \mathrm{IN}_{2} \mathrm{O}_{2}[\mathrm{M}+\mathrm{H}]^{+}$: 354.9944; found: 354.9951 .

Thioether compound 10. Under an Ar atmosphere, in a $50 \mathrm{~mL}$ Schlenk flask, a mixture of 3 (50 mg, $0.163 \mathrm{mmol})$, Xantphos $(9.5 \mathrm{mg}, 0.163 \mu \mathrm{mol})$ and $\mathrm{Pd}(\mathrm{OAc})_{2}(1.8 \mathrm{mg}, 8.15 \mu \mathrm{mol})$ in dry 1,4-dioxane $(1 \mathrm{~mL})$ was degassed under $\mathrm{Ar}$ for $30 \mathrm{~min}$. $i \mathrm{Pr}_{2} \mathrm{NEt}$ (57 $\mu \mathrm{L}, 0.326 \mathrm{mmol})$ and thioacetic acid $(14 \mu \mathrm{L}, 0.196 \mathrm{mmol})$ were then added. The brownish mixture was gently degassed under $\mathrm{Ar}$ for $10 \mathrm{~min}$ and kept at $80^{\circ} \mathrm{C}$ for $3 \mathrm{~h}$. The reaction mixture was evaporated to dryness. The usual work-up with $\mathrm{CH}_{2} \mathrm{Cl}_{2}$ gave a crude product, which was purified by flash chromatography over silica gel (eluting with THF : cyclohexane, $5: 95)$ to give 10 as a yellow powder (37 mg, $77 \%$ ). ${ }^{1} \mathrm{H}$ NMR $\left(\mathrm{CDCl}_{3}\right): \delta 12.50\left(\mathrm{~s}, 2 \mathrm{H}, \mathrm{D}_{2} \mathrm{O}\right.$ exchangeable, $\left.2 \mathrm{OH}\right), 7.74-7.60(\mathrm{~m}$, $4 \mathrm{H}, \mathrm{Ar}), 7.52-7.44(\mathrm{~m}, 2 \mathrm{H}, \mathrm{Ar}), 7.43-7.33(\mathrm{~m}, 2 \mathrm{H}, \mathrm{Ar}), 1.78(\mathrm{~s}, 6 \mathrm{H}$, $\left.2 \mathrm{CH}_{3}\right), 1.57\left(\mathrm{~s}, 6 \mathrm{H}, 2 \mathrm{CH}_{3}\right) .{ }^{13} \mathrm{C} \mathrm{NMR}\left(\mathrm{CDCl}_{3}\right) \delta 192.42(\mathrm{C})$, $152.60(\mathrm{C}), 141.11(\mathrm{C}), 134.48(\mathrm{C}), 128.46(\mathrm{C}), 128.42(\mathrm{CH})$, $127.24(\mathrm{CH}), 126.07(\mathrm{CH}), 116.63(\mathrm{CH}), 94.93(\mathrm{C}), 86.88(\mathrm{C})$, $27.15\left(4 \mathrm{CH}_{3}\right)$. HRMS: m/z calcd. for $\mathrm{C}_{26} \mathrm{H}_{23} \mathrm{~N}_{4} \mathrm{O}_{4} \mathrm{~S}[\mathrm{M}+\mathrm{H}]^{+}$: 487.1440; found: 487.1425 .

Trifluoro-methanesulfonic acid 4-iodo-2,2-dimethyl-2H-1oxa-9,10-diaza-anthracen-3-yl ester (13). Under an $\mathrm{Ar}$ atmosphere, to a solution of $3(155 \mathrm{mg}, 0.438 \mathrm{mmol})$ and $\operatorname{Pr}_{2} \mathrm{NEt}(115 \mu \mathrm{L}, 0.657 \mathrm{mmol})$ in dry $\mathrm{CH}_{2} \mathrm{Cl}_{2}(3 \mathrm{~mL})$ was added at $0{ }^{\circ} \mathrm{C}$ dropwise triflic anhydride (161 mg, $\left.0.569 \mathrm{mmol}\right)$. After 20 minutes at room temperature, water $(1 \mathrm{~mL})$ was added and the usual work-up with $\mathrm{CH}_{2} \mathrm{Cl}_{2}$ gave a crude product, which was purified by flash chromatography over silica gel (eluting with $\mathrm{CH}_{2} \mathrm{Cl}_{2}$ ) the yield a white powder (135 mg, $64 \%$ ). ${ }^{1} \mathrm{H} \mathrm{NMR}$ $\left(\mathrm{CDCl}_{3}\right): \delta 8.14(\mathrm{dd}, J=1.0,8.0 \mathrm{~Hz}, 1 \mathrm{H}, \mathrm{Ar}), 7.90(\mathrm{dd}, J=1.0$, $8.0 \mathrm{~Hz}, 1 \mathrm{H}, \mathrm{Ar}), 7.71(\mathrm{~m}, 2 \mathrm{H}, \mathrm{Ar}), 1.79\left(\mathrm{~s}, 6 \mathrm{H}, 2 \mathrm{CH}_{3}\right) .{ }^{13} \mathrm{C} \mathrm{NMR}$ $\left(\mathrm{CDCl}_{3}\right) \delta 157.38(\mathrm{C}), 151.21(\mathrm{C}), 141.31$ (C), 140.52 (C), $137.21(\mathrm{C}), 131.61(\mathrm{CH}), 129.18(\mathrm{CH}), 128.32(\mathrm{CH}), 127.23$ $(\mathrm{CH}), 118.50$ (q, J $J_{\mathrm{C}, \mathrm{F}}=321.4 \mathrm{~Hz}, \mathrm{CF}_{3}$ ), $94.73(\mathrm{C}), 82.18(\mathrm{C})$, $26.05\left(2 \mathrm{CH}_{3}\right)$. HRMS: $\mathrm{m} / z$ calcd. for $\mathrm{C}_{14} \mathrm{H}_{11} \mathrm{~F}_{3} \mathrm{IN}_{2} \mathrm{O}_{4} \mathrm{~S}[\mathrm{M}+\mathrm{H}]^{+}$: 486.9436; found: 486.9475 .

3,4-bis-(Ethoxycarbonyl-ethylsulfanyl)-2,2-dimethyl-2H-1oxa-9,10-diaza-anthracen (1) and 3-(4-Bromo-2,2-dimethyl2H-1-oxa-9,10-diaza-anthracen-3-ylsulfanyl)-propionic acid ethyl ester (14). Under an Ar atmosphere, in a $250 \mathrm{~mL}$ Schlenk flask, a mixture of 12 ( $3 \mathrm{~g}, 6.83 \mathrm{mmol}$ ), Xantphos (395 mg, 0.683 $\mathrm{mmol}$ ) and $\mathrm{Pd}(\mathrm{dba})_{2}$ (393 $\left.\mathrm{mg}, 0.683 \mathrm{mmol}\right)$ in dry 1,4-dioxane $(60 \mathrm{~mL})$ was degassed under $\mathrm{Ar}$ for $30 \mathrm{~min}$. $\mathrm{PPr}_{2} \mathrm{NEt}(3.6 \mathrm{~mL}$, $20.5 \mathrm{mmol}$ ) and $\mathrm{HSCH}_{2} \mathrm{CH}_{2} \mathrm{CO}_{2} \mathrm{Et}(1.9 \mathrm{~mL}, 15 \mathrm{mmol})$ were then added. The brownish mixture was gently degassed under $\mathrm{Ar}$ for $10 \mathrm{~min}$. and kept at $110^{\circ} \mathrm{C}$ for $3.5 \mathrm{~h}$. The reaction mixture was evaporated to dryness. The usual work-up with $\mathrm{CH}_{2} \mathrm{Cl}_{2}$ gave a crude product, which was purified by flash chromatography over silica gel (eluting with AcOEt : cyclohexane 5 : 95). 1 (a brown oil, $2.08 \mathrm{~g}, 64 \%$ ) and 14 (a brown oil, $535 \mathrm{mg}, 19 \%$ ) were obtained.

1: ${ }^{1} \mathrm{H}$ NMR $\left(\mathrm{CDCl}_{3}\right): \delta 8.06$ (dd, $\left.J=1.5,8.0 \mathrm{~Hz}, 1 \mathrm{H}, \mathrm{Ar}\right), 7.83$ (dd, $J=1.5,8.0 \mathrm{~Hz}, 1 \mathrm{H}, \mathrm{Ar}), 7.66(\mathrm{~m}, 1 \mathrm{H}, \mathrm{Ar}), 7.59(\mathrm{~m}, 1 \mathrm{H}, \mathrm{Ar}), 4.17$ (q, $J=7.0 \mathrm{~Hz}, 2 \mathrm{H}, \mathrm{CH}_{2}$ ), 4.10 (q, $J=7.0 \mathrm{~Hz}, 2 \mathrm{H}, \mathrm{CH}_{2}$ ), 3.33 (t, $J$ $\left.=7.0 \mathrm{~Hz}, 2 \mathrm{H}, \mathrm{CH}_{2}\right), 3.31\left(\mathrm{t}, J=7.0 \mathrm{~Hz}, 2 \mathrm{H}, \mathrm{CH}_{2}\right), 2.67(\mathrm{t}, J=7.0$ $\mathrm{Hz}, 2 \mathrm{H}, \mathrm{CH}_{2}$ ), 2.62 (t, $\left.J=7.0 \mathrm{~Hz}, 2 \mathrm{H}, \mathrm{CH}_{2}\right), 1.74\left(\mathrm{~s}, 6 \mathrm{H}, \mathrm{CH}_{3}\right)$, 1.27 (t, $\left.J=7.0 \mathrm{~Hz}, 3 \mathrm{H}, \mathrm{CH}_{3}\right), 1.21\left(\mathrm{t}, J=7.0 \mathrm{~Hz}, 3 \mathrm{H}, \mathrm{CH}_{3}\right) .{ }^{13} \mathrm{C}$ NMR $\left(\mathrm{CDCl}_{3}\right): \delta 171.53(\mathrm{C}=\mathrm{O}), 171.13(\mathrm{C}=\mathrm{O}), 153.71(\mathrm{C})$, 152.82 (C), 140.83 (C), 139.72 (C), 138.12 (C), 133.41 (C), $130.39(\mathrm{CH}), 129.086(\mathrm{CH}), 127.54(\mathrm{CH}), 127.21(\mathrm{CH}), 85.35$ (C), $60.91\left(\mathrm{CH}_{2}\right), 60.72\left(\mathrm{CH}_{2}\right), 34.76\left(\mathrm{CH}_{2}\right), 34.34\left(\mathrm{CH}_{2}\right), 32.53$ $\left(\mathrm{CH}_{2}\right), 28.67\left(\mathrm{CH}_{2}\right), 25.57\left(\mathrm{CH}_{3}\right), 14.18\left(\mathrm{CH}_{3}\right), 14.12\left(\mathrm{CH}_{3}\right)$. HRMS: $\mathrm{m} / \mathrm{z}$ calcd. for $\mathrm{C}_{23} \mathrm{H}_{29} \mathrm{~N}_{2} \mathrm{O}_{5} \mathrm{~S}_{2}[\mathrm{M}+\mathrm{H}]^{+}:$477.1518; found: 477.1540.

$14:{ }^{1} \mathrm{H}$ NMR $\left(\mathrm{CDCl}_{3}\right): \delta 8.09(\mathrm{dd}, J=1.3,8.2 \mathrm{~Hz}, 1 \mathrm{H}, \mathrm{Ar}), 7.84$ (dd, $J=1.3,8.2 \mathrm{~Hz}, 1 \mathrm{H}, \mathrm{Ar}$ ), $7.65(\mathrm{~m}, 2 \mathrm{H}, \mathrm{Ar}$ ), 4.20 (q, $J=7.1 \mathrm{~Hz}$, $2 \mathrm{H}, \mathrm{CH}_{2}$ ), $3.43\left(\mathrm{t}, J=7.2 \mathrm{~Hz}, 2 \mathrm{H}, \mathrm{CH}_{2}\right), 2.72(\mathrm{t}, J=7.2 \mathrm{~Hz}, 2 \mathrm{H}$, $\mathrm{CH}_{2}$ ), 1.79 (s, $\left.6 \mathrm{H}, \mathrm{CH}_{3}\right), 1.29\left(\mathrm{t}, J=7.1 \mathrm{~Hz}, 3 \mathrm{H}, \mathrm{CH}_{3}\right) .{ }^{13} \mathrm{C} \mathrm{NMR}$ $\left(\mathrm{CDCl}_{3}\right): \delta 171.08(\mathrm{C}=\mathrm{O}), 153.10(\mathrm{C}), 148.67(\mathrm{C}), 141.47(\mathrm{C})$, $139.89(\mathrm{C}), 136.80(\mathrm{C}), 130.88(\mathrm{CH}), 129.24(\mathrm{CH}), 127.75(\mathrm{CH})$, $127.07(\mathrm{CH}), 126.07(\mathrm{C}), 86.31(\mathrm{C}), 61.01\left(\mathrm{CH}_{2}\right), 34.26\left(\mathrm{CH}_{2}\right)$, $31.18\left(\mathrm{CH}_{2}\right), 28.13\left(\mathrm{CH}_{3}\right), 14.19\left(\mathrm{CH}_{3}\right)$. HRMS: $\mathrm{m} / \mathrm{z}$ calcd. for $\mathrm{C}_{18} \mathrm{H}_{20} \mathrm{BrN}_{2} \mathrm{O}_{3} \mathrm{~S}\left[\mathrm{M}+\mathrm{H}^{+}\right.$: 423.0378, 425.0358; found: 423.0383, 425.0369.

Dithin compound 15. A solution of $\left(\mathrm{Bu}_{4} \mathrm{~N}\right)_{2}\left[\mathrm{MoO}(\mathrm{qpdt})_{2}\right](2)$ (30 $\mathrm{mg})$ in $\mathrm{CH}_{3} \mathrm{CN}(2 \mathrm{~mL})$ was allowed to be in contact with air under the fume hood without stirring. After 3 days, orange crystals suitable for X-ray diffraction were obtained ( $6 \mathrm{mg}, 47 \%)$. UV-vis $\left(\mathrm{CH}_{3} \mathrm{CN}\right) \lambda_{\max }\left(\mathrm{am}_{\mathrm{M}} 472\right.$ (840), 393 (13080), 342 (11120) sh, 321 
(12620). ${ }^{1} \mathrm{H}$ NMR $\left(\mathrm{CDCl}_{3}\right): \delta 8.07$ (dd, $J=1.5,8.0 \mathrm{~Hz}, 1 \mathrm{H}, \mathrm{Ar}$ ), 7.84 (dd, $J=1.5,8.0 \mathrm{~Hz}, 1 \mathrm{H}, \mathrm{Ar}), 7.64$ (m, $2 \mathrm{H}, \mathrm{Ar}), 1.89$ (s, $6 \mathrm{H}$, $\left.2 \mathrm{CH}_{3}\right) \cdot{ }^{13} \mathrm{C} \mathrm{NMR}\left(\mathrm{CDCl}_{3}\right): \delta 152.71(\mathrm{C}), 143.87(\mathrm{C}), 140.92(\mathrm{C})$, $139.56(\mathrm{C}), 135.82(\mathrm{C}), 130.36(\mathrm{CH}), 128.87(\mathrm{CH}), 127.69(\mathrm{CH})$, $127.30(\mathrm{CH}), 122.67(\mathrm{C}), 83.54(\mathrm{C}), 28.18\left(2 \mathrm{CH}_{3}\right)$. HRMS: $\mathrm{m} / \mathrm{z}$ calcd. for $\mathrm{C}_{26} \mathrm{H}_{21} \mathrm{~N}_{4} \mathrm{O}_{2} \mathrm{~S}_{2}[\mathrm{M}+\mathrm{H}]^{+}:$: 485.1106 ; found: 485.1102 .

Imino-thiazol compound 18. The experience was carried out thoroughly under an Ar atmosphere by using Schlenk flasks and all solutions were degassed prior to use. To a suspension of $\left[\mathrm{MoCl}_{4}\left(\mathrm{CH}_{3} \mathrm{CN}\right)_{2}\right]^{[17]}(50 \mathrm{mg}, 0.155 \mathrm{mmol})$ in anhydrous THF (10 $\mathrm{mL})$ was added $t$ BuNC (141 $\mu \mathrm{L}, 1.25 \mathrm{mmol})$. After $15 \mathrm{~min}$., $\left[\mathrm{MoCl}_{4}(t \mathrm{BuNC})_{2}\right]$ was formed in situ as a pink solution. Meanwhile and in a separate Schlenk flask, to a solution of $\mathbf{1}$ (148 $\mathrm{mg}, 0.31 \mathrm{mmol}$ ) in anhydrous THF $(3 \mathrm{~mL}$ ) was added $\mathrm{NaH}$ (50 mg, $60 \%$ in mineral oil, $1.24 \mathrm{mmol}$ ) at $0^{\circ} \mathrm{C}$. After $15 \mathrm{~min}$. at room temperature, the dark red solution was slowly transferred to the $\left[\mathrm{MoCl}_{4}(t \mathrm{BuNC})_{2}\right]$ solution via a cannula needle. The color turned to dark brown immediately. The reaction was allowed to stir at room temperature for 1 night. Evaporation of THF in vacuo gave a crude product, which was purified by flash chromatography over silica gel (eluting with $\mathrm{CH}_{2} \mathrm{Cl}_{2}$ ) to furnish a red solid (71 mg, $64 \%$ ). Single crystals were grown by slow evaporation of $\mathrm{CH}_{2} \mathrm{Cl}_{2}$ containing the product. UV-vis $\left(\mathrm{CH}_{3} \mathrm{CN}\right)$ $\lambda_{\max }$ (aM) 524 (11800), 494 (8720), 452 (3620) sh, 423 (1820) sh, 300 (3620). ${ }^{1} \mathrm{H}$ NMR $\left(\mathrm{CDCl}_{3}\right): \delta 9.78-9.47(\mathrm{~m}, 1 \mathrm{H}, \mathrm{Ar}), 7.70-$ $7.59(\mathrm{~m}, 1 \mathrm{H}, \mathrm{Ar}), 7.51-7.34(\mathrm{~m}, 2 \mathrm{H}, \mathrm{Ar}), 1.94\left(\mathrm{~s}, 6 \mathrm{H}, 2 \mathrm{CH}_{3}\right)$, $1.49\left(\mathrm{~s}, 9 \mathrm{H}, 3 \mathrm{CH}_{3}\right) \cdot{ }^{13} \mathrm{C} \mathrm{NMR}\left(\mathrm{CDCl}_{3}\right): \delta 208.89(\mathrm{C}=\mathrm{S}), 152.93$ $(\mathrm{C}), 145.81(\mathrm{C}), 137.22(\mathrm{C}), 128.39(\mathrm{C}), 127.87(\mathrm{CH}), 127.51$ $(\mathrm{CH}), 127.16(\mathrm{CH}), 123.03(\mathrm{C}), 121.23(\mathrm{C}), 118.28(\mathrm{CH}), 96.42$ (C), $56.18(\mathrm{C}), 31.07\left(2 \mathrm{CH}_{3}\right), 27.49\left(3 \mathrm{CH}_{3}\right)$. HRMS: $\mathrm{m} / \mathrm{z}$ calcd. for $\mathrm{C}_{18} \mathrm{H}_{20} \mathrm{~N}_{3} \mathrm{OS}{ }_{2}[\mathrm{M}+\mathrm{H}]^{+}$: 358.1048; found: 358.1061 .

\section{Acknowledgements}

This work was supported by the French National Research Agency (Carbiored ANR-12-BS07-0024-03) and the French State Program 'Investissements d'Avenir' (Grants "LABEX DYNAMO", ANR-11-LABX-0011). Authors thank the Fondation de l'Orangerie for individual Philanthropy. We also thank $L$. Dubost and the Muséum National d'Histoire Naturelle for technical support.

Keywords: dithiolene ligands $\cdot$ molybdenum $\cdot \mathrm{C}-\mathrm{S}$ crosscoupling $\bullet$ cyclic voltammetry $\bullet$ palladium

[1] a) R. J. P. Williams, J. J. R. F. Da Silva, Biochem. Bioph. Res. Co. 2002, 292, 293-299; b) R. Hille, J. Hall, P. Basu, Chem. Rev. 2014, 114, 3963-4038.

[2] a) M. J. Romao, Dalton Trans. 2009, 4053-4068; b) L. B. Maia, J. J. G. Moura, I. Moura, J. Biol. Inorg. Chem. 2015, 20, 287-309.

[3] a) J. H. Enemark, J. J. A. Cooney, J.-J. Wang, R. H. Holm, Chem. Rev. 2004, 104, 1175-1200; b) B. S. Lim, J. P. Donahue, R. H. Holm, Inorg. Chem. 2000, 39, 263-273; c) S. Groysman, R. H. Holm, Inorg. Chem. 2007, 46, 4090-4102.

[4] a) H. Sugimoto, H. Tsukube, Chem. Soc. Rev. 2008, 37, 2609-2619; b) C. Schulzke, Eur. J. Inorg. Chem. 2011, 1189-1199; c) A. Majumdar, S.
Sarkar, Coord. Chem. Rev. 2011, 255, 1039-1054; d) P. Basu, S. J. N. Burgmayer, J. Biol. Inorg. Chem. 2015, 20, 373-383.

[5] a) L. Marbella, B. Serli-Mitasev, P. Basu, Angew. Chem.-Int. Edit. 2009 48, 3996-3998; b) P. Basu, I. Pimkov, U.S. Pat. Appl. Publ., US 20120245168 A1 201209272012.

[6] a) B. Bradshaw, D. Collison, C. D. Garner, J. A. Joule, Chem. Commun 2001, 123-124; b) B. Bradshaw, A. Dinsmore, W. Ajana, D. Collison, C D. Garner, J. A. Joule, J. Chem. Soc.-Perkin Trans. 1 2001, 3239-3244.

[7] a) B. R. Williams, Y. C. Fu, G. P. A. Yap, S. J. N. Burgmayer, J. Am Chem. Soc. 2012, 134, 19584-19587; b) B. R. Williams, D. Gisewhite A. Kalinsky, A. Esmail, S. J. N. Burgmayer, Inorg. Chem. 2015, 54, 8214-8222.

[8] J.-P. Porcher, T. Fogeron, M. Gomez-Mingot, E. Derat, L.-M Chamoreau, Y. Li, M. Fontecave, Angew. Chem. Int. Ed. 2015, in press (DOI: 10.1002/anie.201505607).

[9] D. E. Ames, J. C. Mitchell, C. C. Takundwa, J. Chem. Res.-M 1985 , 1683-1696.

[10] a) P. Chandrasekaran, J. P. Donahue, Org. Synth. 2009, 86, 333-343; b) A. K. Bhattacharya, A. G. Hortmann, J. Org. Chem. 1974, 39, 95-97.

[11] a) T. Itoh, T. Mase, Org. Lett. 2004, 6, 4587-4590; b) T. Itoh, T. Mase, Org. Lett. 2007, 9, 3687-3689.

[12] J. P. Smit, W. Purcell, A. Roodt, J. G. Leipoldt, Polyhedron 1993, 12, 2271-2277.

[13] J. P. Dicks, M. Zubair, E. S. Davies, C. D. Garner, C. Schulzke, C. Wilson, J. McMaster, Eur. J. Inorg. Chem. 2015, 3550-3561.

[14] CCDC 1430930 and 1430931 contain the supplementary crystallographic data for $\mathbf{1 5}$ and 18. These data can be obtained free of charge from The Cambridge Crystallographic Data Centre via www.ccdc.cam.ac.uk/data request/cif.

[15] M. Becker, J. Harloff, T. Jantz, A. Schulz, A. Villinger, Eur. J. Inorg. Chem. 2012, 5658-5667.

[16] W. T. Eckenhoff, W. W. Brennessel, R. Eisenberg, Inorg. Chem. 2014, 53, 9860-9869.

[17] J. R. Dilworth, R. L. Richards, Inorg. Synth. 1990, 28, 33 